\title{
CHAPTER - 2
}

\section{SUICIDES IN INDIA}

Each suicide is a personal tragedy that prematurely takes the life of an individual and has a continuing ripple effect, dramatically affecting the lives of families, friends and communities. Every year, more than $1,00,000$ people commit suicide in our country. There are various causes of suicides like professional/career problems, sense of isolation, abuse, violence, family problems, mental disorders, addiction to alcohol, financial loss, chronic pain etc. NCRB collects data on suicides from police recorded suicide cases.
Rate of suicides has been calculated using projected population for the non-census years whereas for the census year 2011, the population of the Population Census 2011 was used.

A total of $1,34,516$ suicides were reported in the country during 2018 showing an increase of $3.6 \%$ in comparison to 2017 and the rate of suicides has increased by 0.3 during 2018 over 2017. [Table-2 (A)] The incidence and rate of suicides during $2008-2018$ is presented in Table-2.1.

Table - 2 (A)

Number of Suicides, Growth of Population and Rate of Suicides during 2014 - 2018

\begin{tabular}{|c|c|c|c|c|}
\hline $\begin{array}{l}\text { SI. } \\
\text { No. }\end{array}$ & Year & $\begin{array}{l}\text { Total Number of } \\
\text { Suicides }\end{array}$ & $\begin{array}{l}\text { Mid-Year Projected } \\
\text { Population* } \\
\text { (in Lakh)+ }\end{array}$ & $\begin{array}{l}\text { Rate of Suicides }{ }^{* * *} \\
\text { (Col.3/Col.4) }\end{array}$ \\
\hline (1) & (2) & (3) & (4) & (5) \\
\hline 1 & 2014 & $1,31,666$ & $12,440.4$ & 10.6 \\
\hline 2 & 2015 & $1,33,623$ & $12,591.1$ & 10.6 \\
\hline 3 & 2016 & $1,31,008$ & $12,739.9$ & 10.3 \\
\hline 4 & 2017 & $1,29,887$ & 13091.6\# & 9.9 \\
\hline 5 & 2018 & $1,34,516$ & $13233.8 \#$ & 10.2 \\
\hline $\begin{array}{l}\text { Source: } \\
\text { Source: }\end{array}$ & \multicolumn{4}{|c|}{$\begin{array}{l}\text { The Registrar General of India. } \\
\text { Report of the Technical Group on Population Projections (November, 2019), National Commission on } \\
\text { Population, Ministry of Health \& Family Welfare. }\end{array}$} \\
\hline $\begin{array}{l}\text { One Lakl } \\
{ }^{* *} \text { Rate of } S\end{array}$ & $\begin{array}{l}h=0.1 \text { Millio } \\
\text { suicides }=\operatorname{lnc}\end{array}$ & $\begin{array}{l}\text { e of suicides per one lakh } \\
\text { States/UTs. }\end{array}$ & 00,000 ) of population. & \\
\hline
\end{tabular}




\section{Number and Percentage Share of Suicides in States/UTs}

The State/UT and City wise information on the incidents of suicides, its percentage share in total suicides and rate of suicides during the year are presented in Table-2.2.

Majority of suicides were reported in Maharashtra $(17,972)$ followed by 13,896 suicides in Tamil Nadu, 13,255 suicides in West Bengal, 11,775 suicides in Madhya Pradesh and 11,561 suicides in Karnataka accounting for $13.4 \%, 10.3 \%, 9.9 \%, 8.8 \%$ and $8.6 \%$ of total suicides respectively. These 5 States together accounted for $50.9 \%$ of the total suicides reported in the country. The remaining $49.1 \%$ suicides were reported in the remaining 24 States and 7 UTs. Uttar Pradesh, the most populous State $(16.9 \%$ share of country population) has reported comparatively lower percentage share of suicidal deaths, accounting for only $3.6 \%$ of the total suicides reported in the country.

The States which have witnessed significantly higher number of suicidal deaths during the year 2016 to 2018 are presented in the Table-2(B). These States have continuously accounted for about $7.0 \%$ or more of the total suicides reported in the country from 2016 to 2018.

\section{Figure - 2.1}

\section{State/UT wise Major Percentage Share of Suicides in States during 2018}

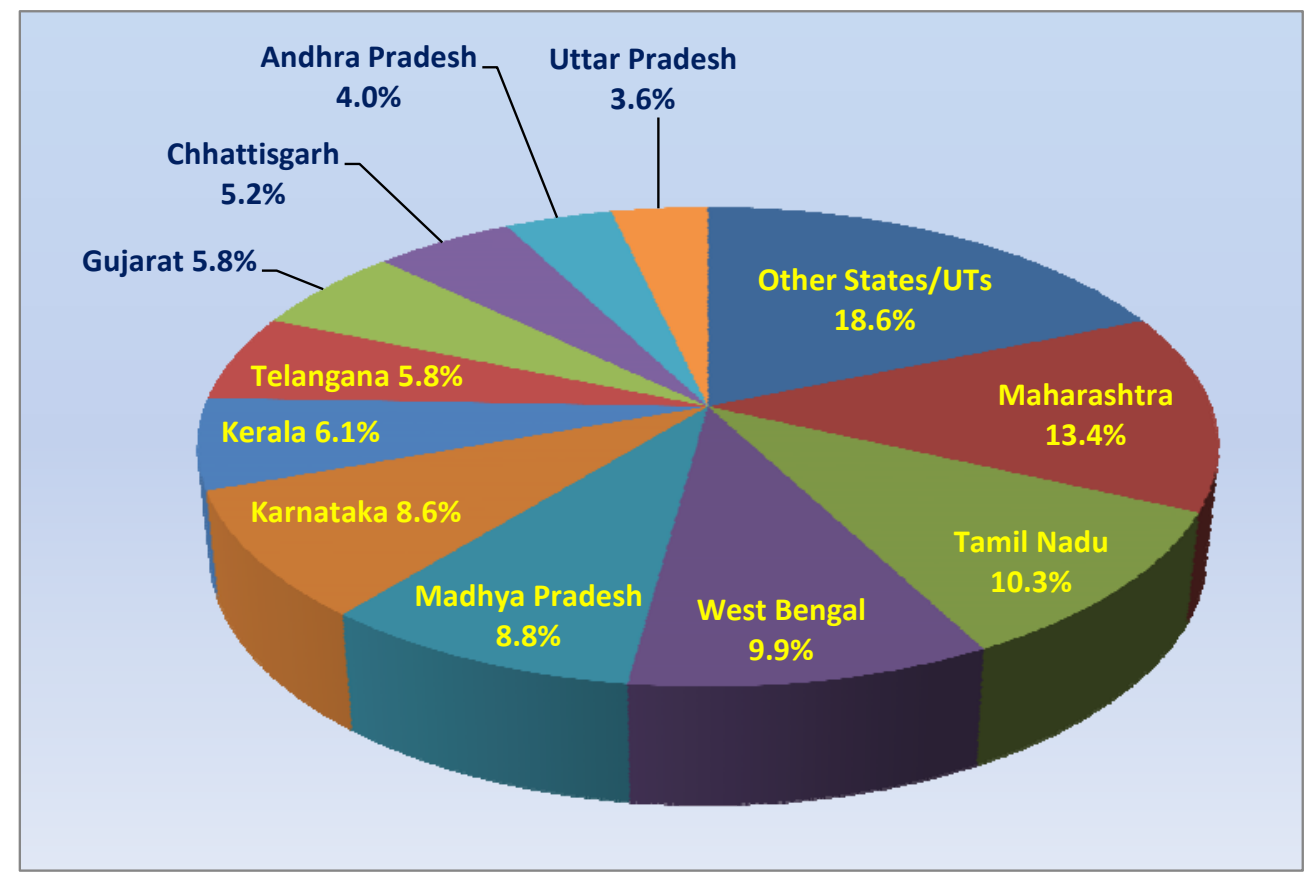

- As per data provided by States/UTs.

Note: OTHER STATES/UTs include Arunachal Pradesh, Assam, Bihar, Goa, Haryana, Himachal Pradesh, Jammu \& Kashmir, Jharkhand, Manipur, Mizoram, Nagaland, Meghalaya, Punjab, Rajasthan, Sikkim, Tripura, Odisha, Uttarakhand, A \& N Island, Chandigarh, D \& N Haveli, Daman \& Diu, Delhi, Lakshadweep and Puducherry 

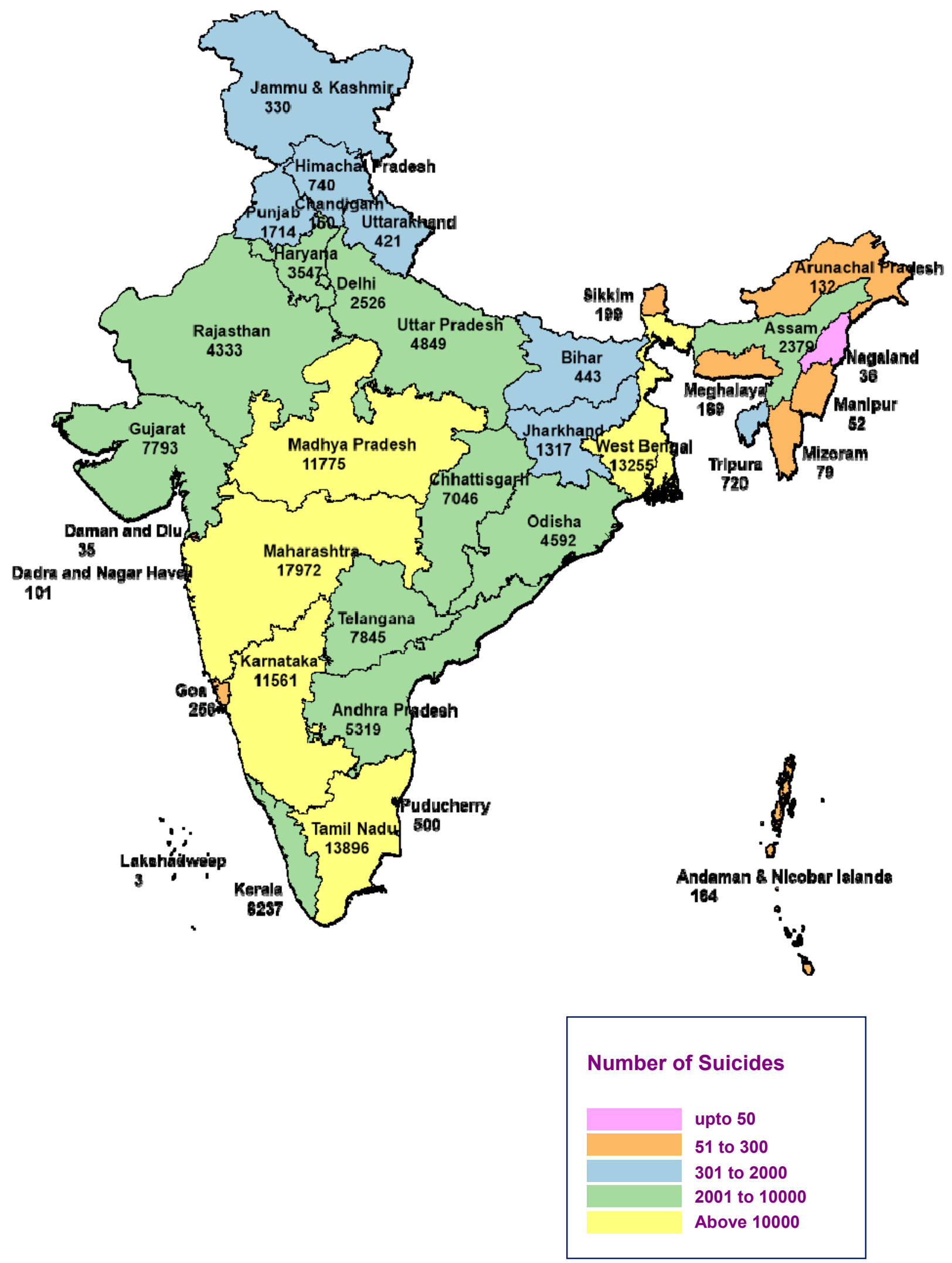

Map Powered by DevInfo, UNICEF

- As per data provided by States/UTs. 
Table - 2 (B)

States with Higher Percentage Share of Suicides during 2016 to 2018

\begin{tabular}{cllllll}
\hline SI. & \multicolumn{5}{c}{ Year } \\
\cline { 2 - 7 } No. & \multicolumn{2}{c}{2016} & \multicolumn{2}{c}{2017} & \multicolumn{2}{c}{2018} \\
\hline 1 & Maharashtra & $(13.1 \%)$ & Maharashtra & $(13.6 \%)$ & Maharashtra & $(13.4 \%)$ \\
2 & Tamil Nadu & $(11.6 \%)$ & Tamil Nadu & $(11.1 \%)$ & Tamil Nadu & $(10.3 \%)$ \\
3 & West Bengal & $(10.3 \%)$ & West Bengal & $(9.2 \%)$ & West Bengal & $(9.9 \%)$ \\
4 & Karnataka & $(8.2 \%)$ & Madhya Pradesh & $(9.1 \%)$ & Madhya Pradesh & $(8.8 \%)$ \\
5 & Madhya Pradesh & $(8.0 \%)$ & Karnataka & $(9.0 \%)$ & Karnataka & $(8.6 \%)$ \\
\hline
\end{tabular}

- As per data provided by States/UTs.

Delhi, which is the most-populous UT, has reported the highest number of suicides $(2,526)$ among UTs, followed by Puducherry (500). Seven UTs together accounted for $2.6 \%$ of total suicides in the country. A total of 21,408 suicides were reported in the 53 mega cities of the country during the 2018.

The States and UTs which have reported significant percentage increase in suicides in 2018 over 2017 were Arunachal Pradesh (48.3\%), Chandigarh (41.6\%), D \& N Haveli (34.7\%), Himachal Pradesh (28.5\%), Uttarakhand (27.2\%) and Manipur (20.9\%) while highest percentage decrease was reported in Daman \& Diu (14.6\%), Puducherry
(13.9\%), Mizoram (13.2\%), Sikkim (7.0\%) and Goa (6.2\%) [Table-2.3].

Rate of Suicides - Trend in States/UTs

Rate of suicides i.e. the number of suicides per one lakh population, has been widely accepted as a standard yardstick for comparison. All India rate of suicides was 10.2 during the year 2018. A \& N Islands reported the highest rate of suicide (41.0) followed by Puducherry (33.8), Sikkim (30.2), Chhattisgarh (24.7) and Kerala (23.5). The details of States/UTs which have recorded higher rate of suicides during 2016 to 2018 are given in Table-2(C).

Figure $-\mathbf{2 . 2}$

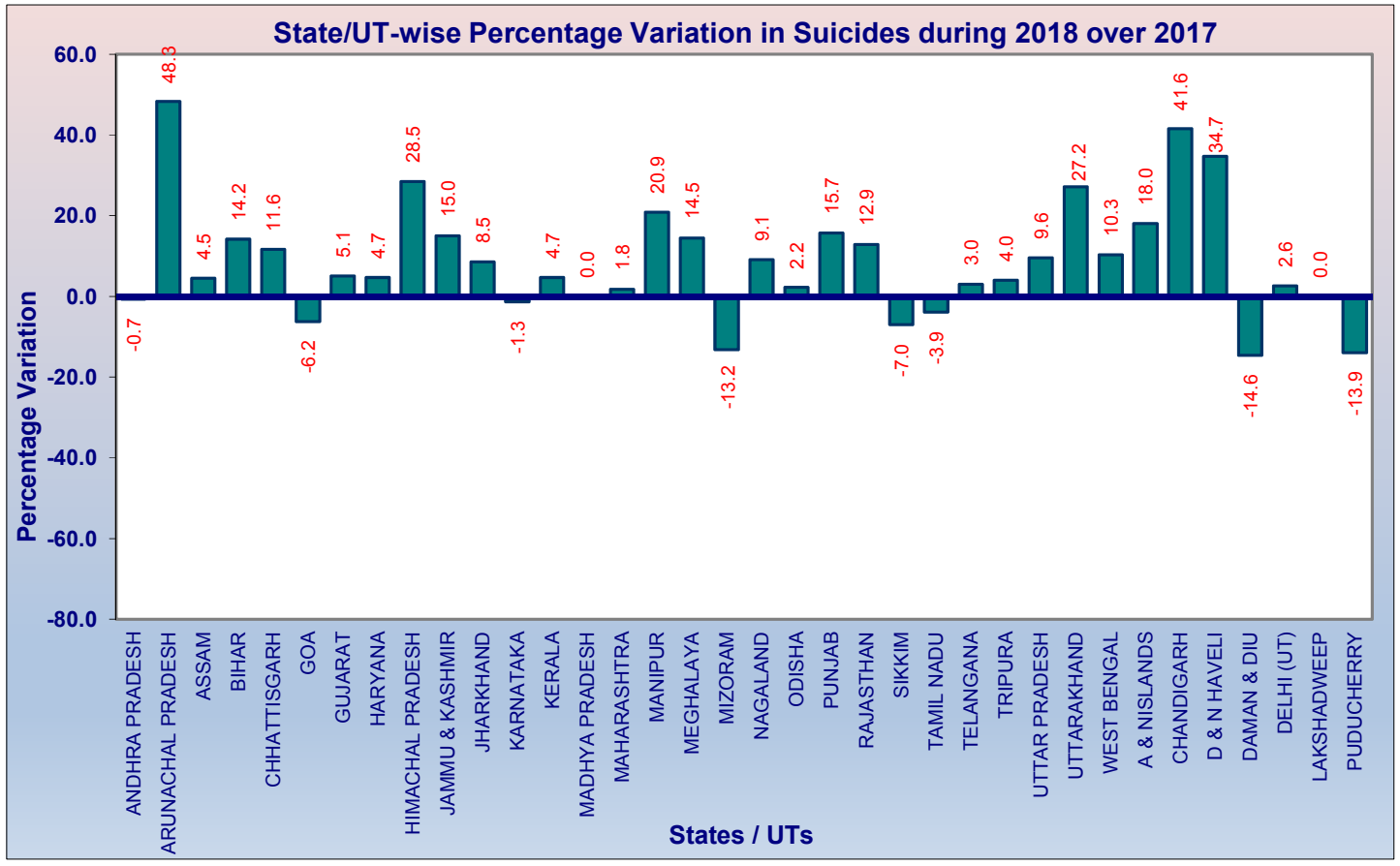

- As per data provided by States/UTs. 
Figure $-\mathbf{2 . 3}$

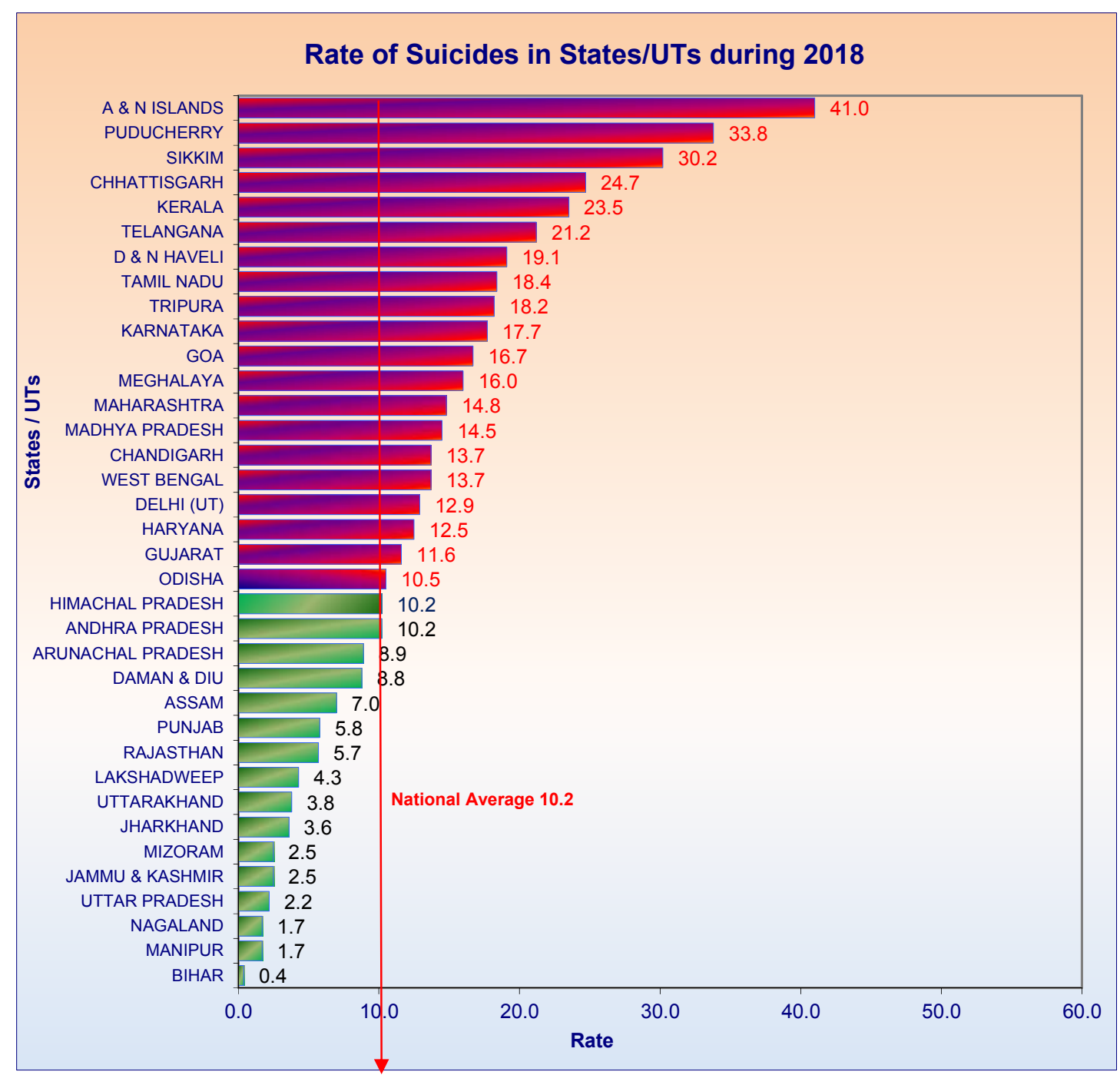

- As per data provided by States/UTs. 


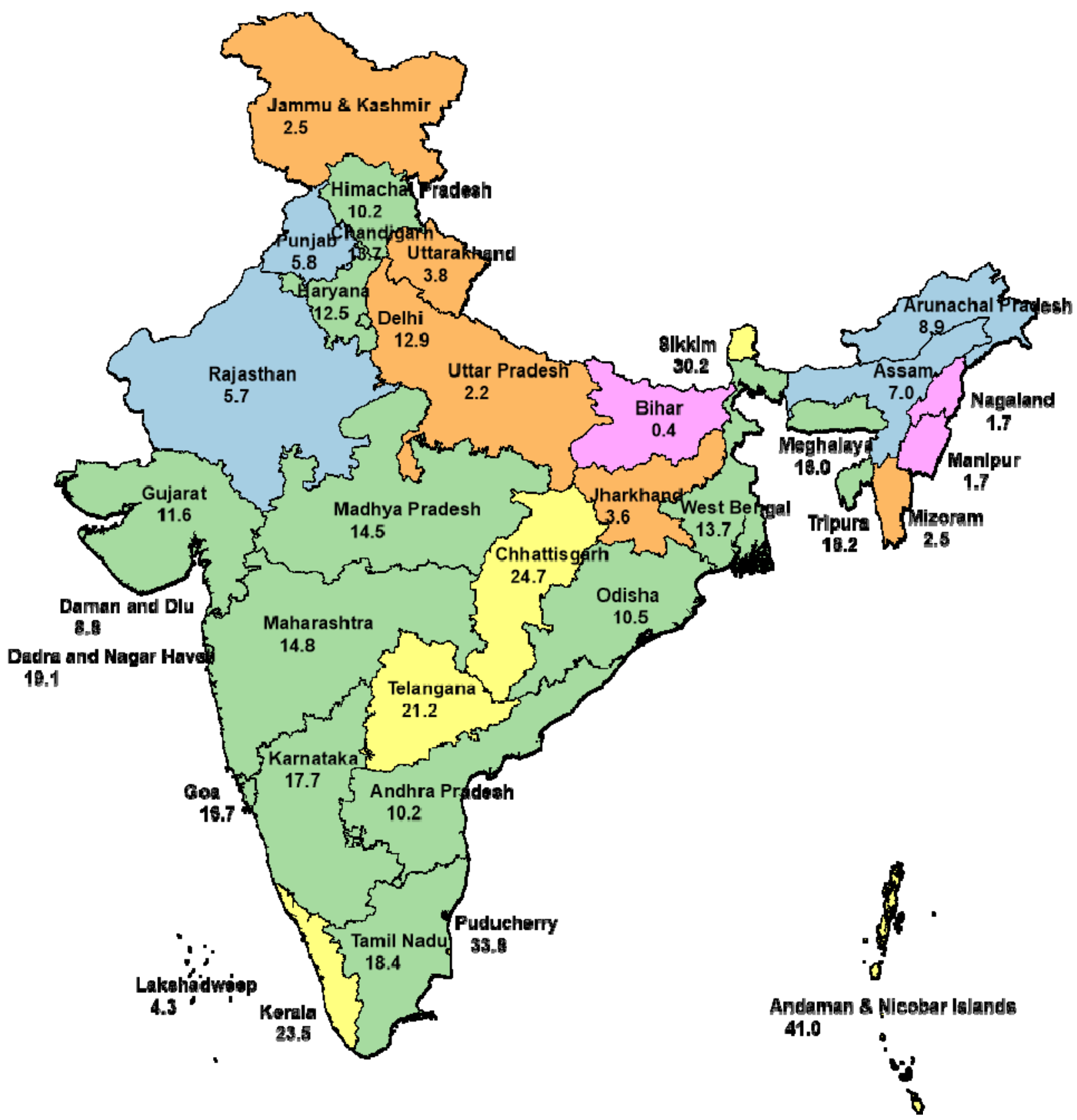

Note:

Suicide Rate means Number of Suicides per One Lakh population.

Suicide Rate

All India Average 10.2

upto 2

3 to 5

6 to 10

11 to 20

Above 20 
Table - 2 (C)

States/UTs with Higher Suicide Rate during 2016 to 2018

\begin{tabular}{lclllc}
\hline \multicolumn{1}{c}{ 2016 } & \multicolumn{2}{c}{ 2017 } \\
\hline Sikkim & 40.5 & Puducherry & 40.1 & A \& N Islands & 41.0 \\
Puducherry & 33.3 & A \& N Islands & 35.6 & Puducherry & 33.8 \\
A \& N Islands & 26.4 & Sikkim & 32.9 & Sikkim & 30.2 \\
Chhattisgarh & 25.8 & Kerala & 22.6 & Kerala & 23.5 \\
Telangana & 24.5 & Chhattisgarh & 22.5 & Telangana & 21.2 \\
National Rate & $\mathbf{( 1 0 . 3 )}$ & National Rate & $\mathbf{( 9 . 9 )}$ & National Rate & $(\mathbf{1 0 . 2})$ \\
\hline
\end{tabular}

- $\quad$ As per data provided by States/UTs.

\section{Causes of Suicides}

'Family Problems' and 'Illness' were the major causes of suicides which accounted for $30.4 \%$ and $17.7 \%$ of total suicides respectively during 2018. 'Marriage Related Issues' (6.2\%), 'Drug Abuse/Addiction' (5.3\%)
'Love Affairs' (4.0\%), 'Bankruptcy or Indebtedness' (3.7\%), 'Failure in Examination' and 'Unemployment' (2.0\% each), 'Professional/Career Problem' (1.3\%) and 'Property Dispute' $(0.9 \%)$ were other causes of suicides [Table-2.4].

Figure -2.4

Percentage Share of Various Causes of Suicides During 2018

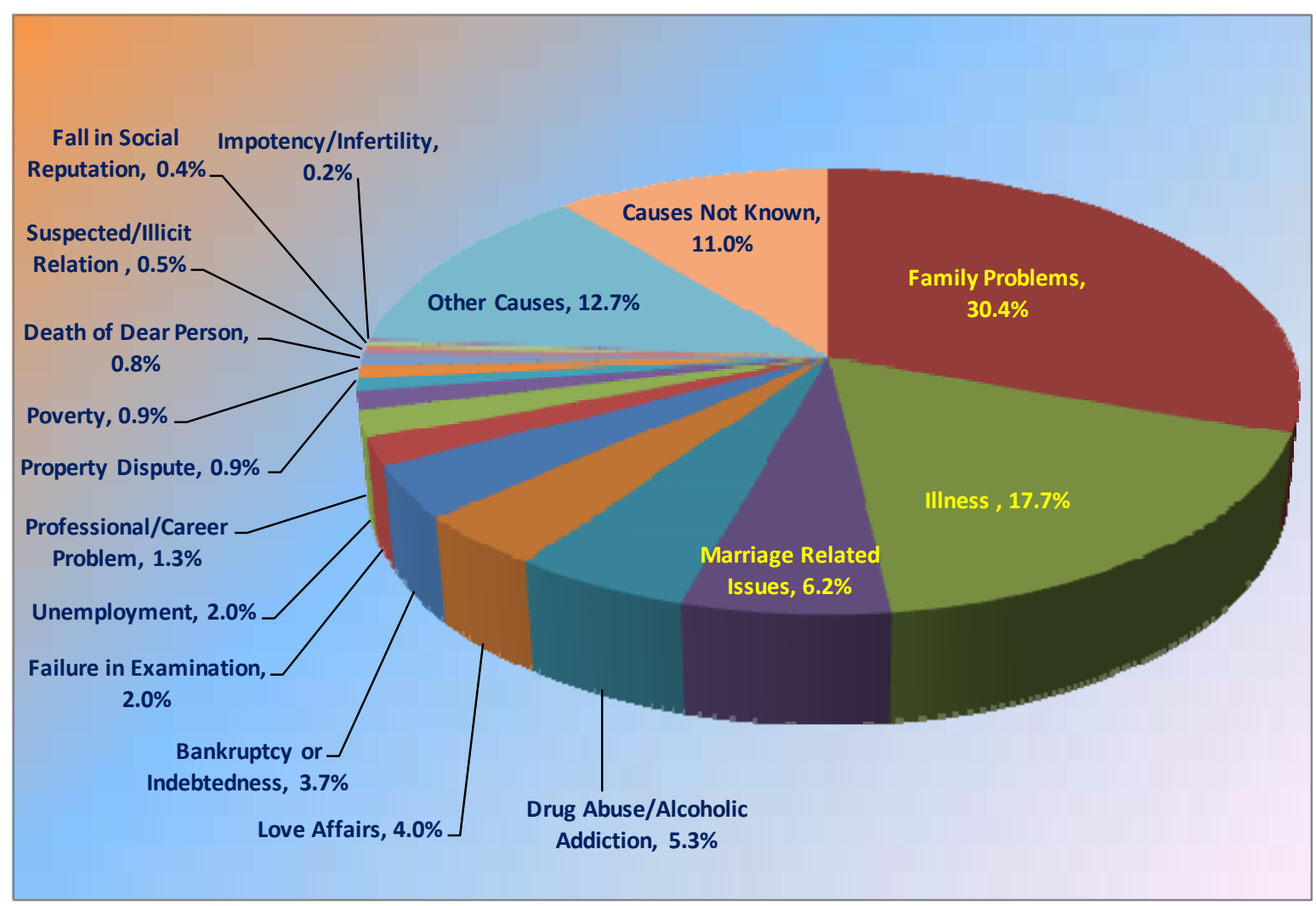

- $\quad$ As per data provided by States/UTs.

* Figure of Suicides due to ideological causes/hero worshiping, physical abuse (rape etc.) and illegitimate pregnancy included along with Other Causes. 
State and UT wise and City wise details on various causes of suicides are presented in Table-2.5. The States/UTs which reported more than the All-India average share under the two major causes of suicides i.e. 'Illness' and 'Family Problems' are grouped in the Table-2(D).

\section{Suicide Victims by Sex and Age Group}

Age group wise distribution of suicides by causes during 2018 is presented in Table2(E). The overall male: female ratio of suicide
15 States/UTs have reported higher percentage share than the All India average in suicides due to 'Illness'. Similarly, 17 States/UTs have reported higher share than the All India average in suicides committed due to 'Family Problems' during the year 2018.

\section{Professional Status of Suicide Victims}

Details on professional status of suicide victims are presented in Table-2.6. Housewives accounted for $54.1 \%$ of the total female victims $(22,937$ out of 42,391$)$ and constitute

Table - 2 (D)

States \& UTs Reporting Higher Share of Suicides due to Illness and Family Problems during 2018

\begin{tabular}{|c|c|c|c|c|c|c|c|}
\hline \multicolumn{4}{|c|}{ IIIness } & \multicolumn{4}{|c|}{ Family Problems } \\
\hline \multicolumn{8}{|c|}{ All India \% Share } \\
\hline \multicolumn{4}{|c|}{$17.7 \%$} & \multicolumn{4}{|c|}{$30.4 \%$} \\
\hline SI. No. & State/UT & Suicides & $\%$ Share & SI. No. & State/UT & Suicides & $\%$ Share \\
\hline 1 & Punjab & 722 & 42.1 & 1 & Manipur & 32 & 61.5 \\
\hline 2 & Sikkim & 82 & 41.2 & 2 & Daman \& Diu & 21 & 60.0 \\
\hline 3 & Lakshadweep & 1 & 33.3 & 3 & Tripura & 388 & 53.9 \\
\hline 4 & Andhra Pradesh & 1610 & 30.3 & 4 & Chandigarh & 84 & 52.5 \\
\hline 5 & Puducherry & 150 & 30.0 & 5 & Tamil Nadu & 6433 & 46.3 \\
\hline 6 & A \& $N$ Islands & 46 & 28.0 & 6 & Kerala & 3213 & 39.0 \\
\hline 7 & Karnataka & 3180 & 27.5 & 7 & Uttar Pradesh & 1872 & 38.6 \\
\hline 8 & Kerala & 2122 & 25.8 & 8 & Telangana & 2972 & 37.9 \\
\hline 9 & Goa & 60 & 23.4 & 9 & Uttarakhand & 150 & 35.6 \\
\hline 10 & Gujarat & 1709 & 21.9 & 10 & Maharashtra & 6072 & 33.8 \\
\hline 11 & Tamil Nadu & 3034 & 21.8 & 11 & D \& N Haveli & 34 & 33.7 \\
\hline 12 & Haryana & 697 & 19.7 & 12 & Bihar & 146 & 33.0 \\
\hline 13 & Maharashtra & 3530 & 19.6 & 13 & Odisha & 1460 & 31.8 \\
\hline 14 & Madhya Pradesh & 2279 & 19.4 & 14 & Jammu \& Kashmir & 104 & 31.5 \\
\hline \multirow[t]{3}{*}{15} & Tripura & 138 & 19.2 & 15 & Delhi (UT) & 787 & 31.2 \\
\hline & & & & 16 & Madhya Pradesh & 3649 & 31.0 \\
\hline & & & & 17 & Rajasthan & 1339 & 30.9 \\
\hline
\end{tabular}

- As per data provided by States/UTs.

victims for the year 2018 was 68.5:31.5, which remains same as compared to year 2017 (68.5:31.5). The proportion of female victims were more in 'Marriage Related Issues' specifically in 'Dowry Related Issues', and 'Impotency/Infertility'. The age group (18 and above - below 30 years) and persons above 30 years - below 45 years of age were the most vulnerable groups resorting to suicides. These age groups accounted for $34.9 \%$ and $31.6 \%$ suicides respectively. 'Family Problems' (2,236), 'Failure in Examination' (1,529), 'Love Affairs' (1,131) and 'lllness' (932) were the main causes of suicides among children (below 18 years of age). nearly $17.1 \%$ of total victims who committed suicides $(22,937$ out of 1,34,516) during 2018.

Government servants accounted for 1.3\% $(1,707$ out of $1,34,516)$ of the total suicide victims as compared to $6.1 \%(8,246$ out of 1,34,516) of total victims from Private Sector Enterprises. Employees from Public Sector Undertakings formed $1.5 \% \quad(2,022$ out of $1,34,516)$ of the total suicide victims, whereas students and un-employed victims accounted for $7.6 \%(10,159$ victims $)$ and $9.6 \%(12,936$ victims) of total suicides respectively. Selfemployed category accounted for $9.8 \%$ of total suicide victims $(13,149$ out of $1,34,516)$. 
A total of 10,349 persons involved in farming sector (consisting of 5,763 farmers/cultivators and 4,586 agricultural labourers) have committed suicides during 2018 , accounting for $7.7 \%$ of total suicides victims $(1,34,516)$ in the country. Out of 5,763 farmer/cultivator suicides, a total of 5,457 were male and 306 were female during 2018. Out of 4,586 suicides committed by agricultural labourers during 2018, 4,071 were male and 515 were female.

Certain States/UTs namely, West Bengal, Bihar, Odisha, Uttarakhand, Meghalaya, Goa, Chandigarh, Daman \& Diu, Delhi UT, Lakshadweep and Puducherry reported zero suicides of Farmers/Cultivators as well as Agricultural Labourers.

Figure - 2.5

Suicide Victims by Sex and Age Group during 2018

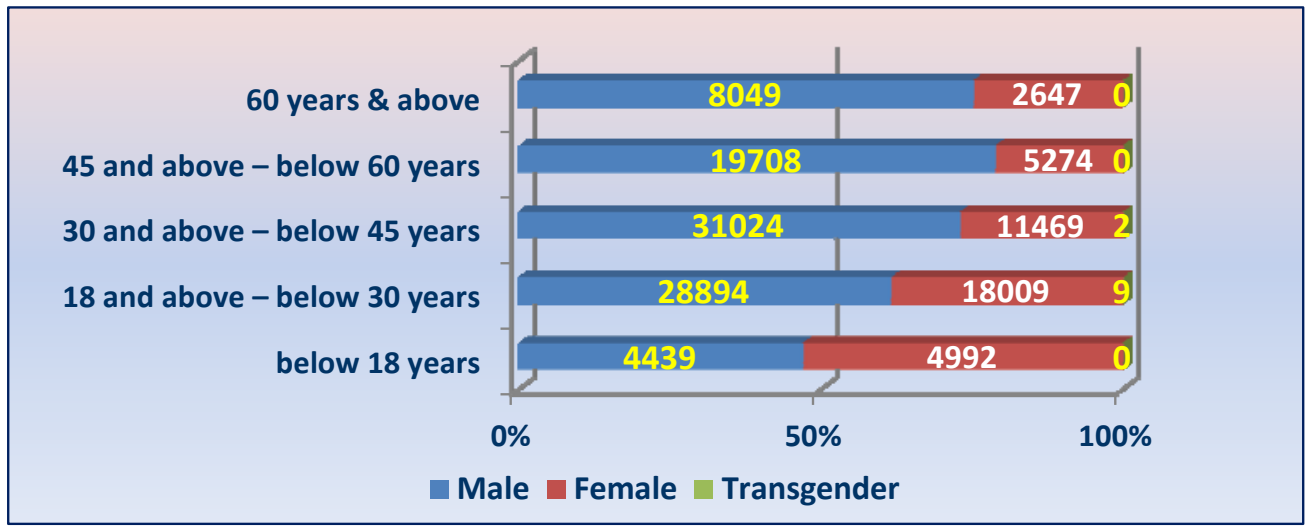

- As per data provided by States/UTs.

Figure -2.6

\section{Percentage Distribution of Suicide Victims by Profession During 2018}

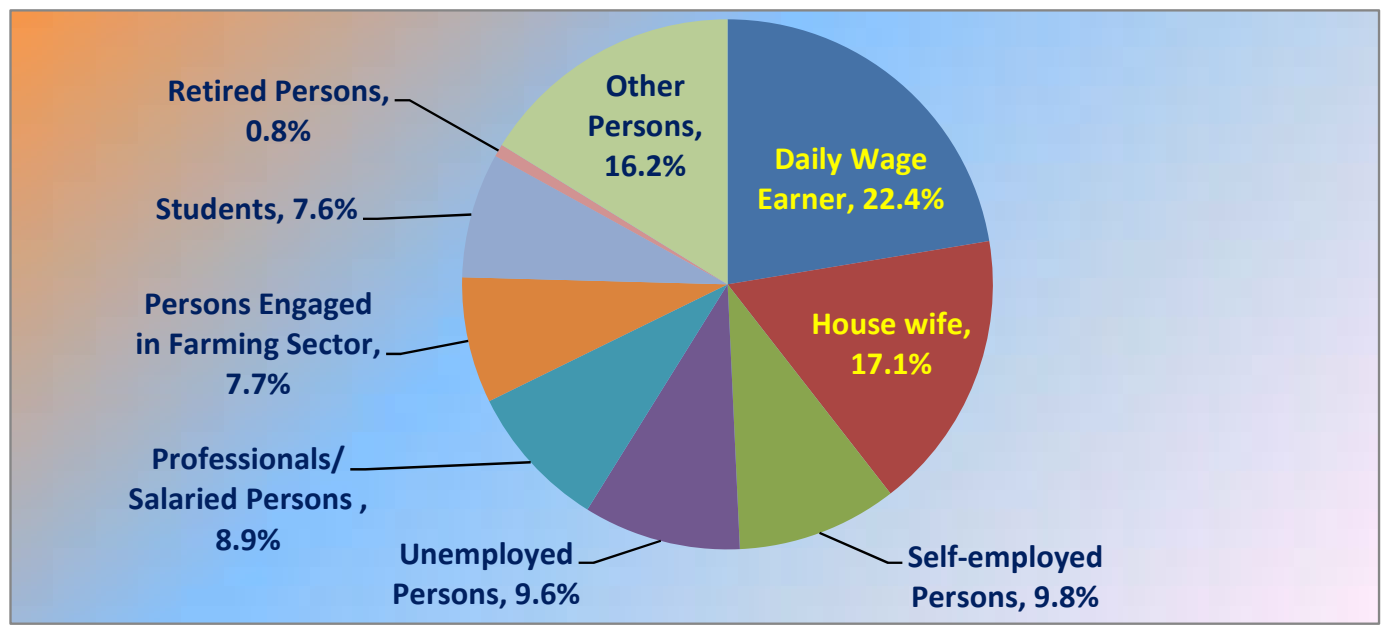

- As per data provided by States/UTs. 
Table 2(E)

Age and Gender - wise Distribution of Suicides during 2018

(Cause-wise)

\begin{tabular}{|c|c|c|c|c|c|c|c|c|c|c|c|c|c|}
\hline \multirow{2}{*}{$\begin{array}{l}\text { SI. } \\
\text { No. }\end{array}$} & \multirow{2}{*}{ Cause } & \multicolumn{4}{|c|}{ Below 18 years } & \multicolumn{4}{|c|}{18 yrs. - Below 30 years } & \multicolumn{4}{|c|}{30 yrs. - Below 45 years } \\
\hline & & M & $\mathbf{F}$ & $\operatorname{Tr}$ & $\mathbf{T}$ & M & $\mathbf{F}$ & $\operatorname{Tr}$ & $\mathbf{T}$ & $\mathbf{M}$ & $\mathbf{F}$ & $\operatorname{Tr}$ & $\mathbf{T}$ \\
\hline (1) & (2) & (3) & (4) & $(5)$ & (6) & (7) & (8) & (9) & (10) & (11) & (12) & (13) & $(14)$ \\
\hline 1 & Bankruptcy or Indebtedness & 7 & 1 & 0 & 8 & 731 & 123 & 0 & 854 & 1774 & 179 & 0 & 1953 \\
\hline 2 & $\begin{array}{l}\text { Marriage Related Issues } \\
\text { (Total) }\end{array}$ & 135 & 163 & 0 & 298 & 1516 & 2926 & 0 & 4442 & 1537 & 1314 & 0 & 2851 \\
\hline & $\begin{array}{l}\text { 2.1 Non Settlement of } \\
\text { Marriage }\end{array}$ & 30 & 53 & 0 & 83 & 676 & 647 & 0 & 1323 & 690 & 299 & 0 & 989 \\
\hline & $\begin{array}{l}\text { 2.2 Dowry Related } \\
\text { Issues }\end{array}$ & 57 & 23 & 0 & 80 & 51 & 1343 & 0 & 1394 & 45 & 455 & 0 & 500 \\
\hline & 2.3 Extra Marital Affairs & 5 & 10 & 0 & 15 & 272 & 363 & 0 & 635 & 290 & 222 & 0 & 512 \\
\hline & 2.4 Divorce & 9 & 5 & 0 & 14 & 103 & 147 & 0 & 250 & 143 & 118 & 0 & 261 \\
\hline & 2.5 Others & 34 & 72 & 0 & 106 & 414 & 426 & 0 & 840 & 369 & 220 & 0 & 589 \\
\hline 3 & Failure in Examination & 757 & 772 & 0 & 1529 & 648 & 386 & 0 & 1034 & 45 & 8 & 0 & 53 \\
\hline 4 & Impotency/Infertility & 2 & 7 & 0 & 9 & 35 & 74 & 0 & 109 & 50 & 86 & 0 & 136 \\
\hline 5 & Family Problems & 979 & 1257 & 0 & 2236 & 8456 & 5940 & 0 & 14396 & 9868 & 4228 & 1 & 14097 \\
\hline 6 & IIIness (Total) & 416 & 516 & 0 & 932 & 3617 & 2109 & 3 & 5729 & 4817 & 1989 & 0 & 6806 \\
\hline & 6.1 AIDS/STD & 2 & 0 & 0 & 2 & 31 & 8 & 0 & 39 & 65 & 11 & 0 & 76 \\
\hline & 6.2 Cancer & 3 & 6 & 0 & 9 & 128 & 44 & 0 & 172 & 259 & 93 & 0 & 352 \\
\hline & 6.3 Paralysis & 11 & 8 & 0 & 19 & 118 & 36 & 0 & 154 & 224 & 65 & 0 & 289 \\
\hline & $\begin{array}{l}6.4 \text { Insanity/ Mental } \\
\text { Illness }\end{array}$ & 247 & 245 & 0 & 492 & 1969 & 889 & 1 & 2859 & 2264 & 858 & 0 & 3122 \\
\hline & $\begin{array}{l}\text { 6.5 Other Prolonged } \\
\text { Illness }\end{array}$ & 153 & 257 & 0 & 410 & 1371 & 1132 & 2 & 2505 & 2005 & 962 & 0 & 2967 \\
\hline 7 & Death of Dear Person & 16 & 21 & 0 & 37 & 198 & 99 & 0 & 297 & 226 & 119 & 0 & 345 \\
\hline 8 & $\begin{array}{l}\text { Drug Abuse/Alcoholic } \\
\text { Addiction }\end{array}$ & 46 & 9 & 0 & 55 & 1745 & 28 & 1 & 1774 & 2797 & 64 & 0 & 2861 \\
\hline 9 & Fall in Social Reputation & 13 & 13 & 0 & 26 & 105 & 51 & 2 & 158 & 144 & 38 & 0 & 182 \\
\hline 10 & $\begin{array}{l}\text { Ideological Causes/Hero } \\
\text { Worshipping }\end{array}$ & 7 & 7 & 0 & 14 & 18 & 19 & 0 & 37 & 19 & 10 & 0 & 29 \\
\hline 11 & Love Affairs & 466 & 665 & 0 & 1131 & 2168 & 1335 & 0 & 3503 & 414 & 240 & 0 & 654 \\
\hline 12 & Poverty & 17 & 14 & 0 & 31 & 302 & 59 & 0 & 361 & 398 & 71 & 0 & 469 \\
\hline 13 & Unemployment & 31 & 9 & 0 & 40 & 1240 & 180 & 0 & 1420 & 868 & 95 & 0 & 963 \\
\hline 14 & Property Dispute & 24 & 4 & 0 & 28 & 216 & 70 & 0 & 286 & 329 & 66 & 0 & 395 \\
\hline 15 & $\begin{array}{l}\text { Suspected/ Illicit Relation } \\
\text { (Other than SI. No. 2.3) }\end{array}$ & 18 & 13 & 0 & 31 & 166 & 137 & 0 & 303 & 173 & 77 & 0 & 250 \\
\hline 16 & $\begin{array}{l}\text { Illegitimate Pregnancy } \\
\text { (Other than SI. No. 2.3) }\end{array}$ & 0 & 5 & 0 & 5 & 0 & 24 & 0 & 24 & 0 & 13 & 0 & 13 \\
\hline 17 & Physical Abuse (Rape, etc.) & 9 & 24 & 0 & 33 & 18 & 23 & 0 & 41 & 29 & 22 & 1 & 52 \\
\hline 18 & $\begin{array}{l}\text { Professional/Career } \\
\text { Problem }\end{array}$ & 22 & 26 & 0 & 48 & 445 & 121 & 0 & 566 & 566 & 86 & 0 & 652 \\
\hline 19 & Causes Not Known & 639 & 722 & 0 & 1361 & 3600 & 2100 & 1 & 5701 & 3208 & 1250 & 0 & 4458 \\
\hline 20 & Other Causes & 835 & 744 & 0 & 1579 & 3670 & 2205 & 2 & 5877 & 3762 & 1514 & 0 & 5276 \\
\hline 21 & Total & 4439 & 4992 & 0 & 9431 & 28894 & 18009 & 9 & 46912 & 31024 & 11469 & 2 & 42495 \\
\hline
\end{tabular}

Note: 'M'- refers to Male, ' $F$ '- refers to Female, 'Tr'- refers to Transgender and 'T' - Total

- As per data provided by States/UTs. 
Table 2(E)

Age and Gender - wise distribution of Suicides during 2018 (Concluded) (Cause-wise)

\begin{tabular}{|c|c|c|c|c|c|c|c|c|c|c|c|c|c|}
\hline \multirow{2}{*}{ SI. No } & \multirow{2}{*}{ Cause } & \multicolumn{4}{|c|}{45 yrs. - Below 60 years } & \multicolumn{4}{|c|}{60 years $\&$ above } & \multicolumn{4}{|c|}{ Total } \\
\hline & & M & $\mathbf{F}$ & $\operatorname{Tr}$ & $\mathbf{T}$ & $\mathbf{M}$ & $\mathbf{F}$ & $\mathrm{Tr}$ & $\mathbf{T}$ & M & $\mathbf{F}$ & $\mathrm{Tr}$ & $\mathrm{T}$ \\
\hline (1) & (2) & (15) & (16) & (17) & (18) & (19) & (20) & (21) & (22) & (23) & (24) & (25) & (26) \\
\hline 1 & Bankruptcy or Indebtedness & 1562 & 127 & 0 & 1689 & 434 & 32 & 0 & 466 & 4508 & 462 & 0 & 4970 \\
\hline 2 & $\begin{array}{l}\text { Marriage Related Issues } \\
\text { (Total) }\end{array}$ & 395 & 180 & 0 & 575 & 107 & 11 & 0 & 118 & 3690 & 4594 & 0 & 8284 \\
\hline & $\begin{array}{l}\text { 2.1 Non Settlement of } \\
\text { Marriage }\end{array}$ & 125 & 39 & 0 & 164 & 24 & 2 & 0 & 26 & 1545 & 1040 & 0 & 2585 \\
\hline & $\begin{array}{l}\text { 2.2 Dowry Related } \\
\text { Issues }\end{array}$ & 10 & 30 & 0 & 40 & 1 & 1 & 0 & 2 & 164 & 1852 & 0 & 2016 \\
\hline & 2.3 Extra Marital Affairs & 66 & 34 & 0 & 100 & 0 & 1 & 0 & 1 & 633 & 630 & 0 & 1263 \\
\hline & 2.4 Divorce & 43 & 32 & 0 & 75 & 45 & 1 & 0 & 46 & 343 & 303 & 0 & 646 \\
\hline & 2.5 Others & 151 & 45 & 0 & 196 & 37 & 6 & 0 & 43 & 1005 & 769 & 0 & 1774 \\
\hline 3 & Failure in Examination & 2 & 5 & 0 & 7 & 1 & 1 & 0 & 2 & 1453 & 1172 & 0 & 2625 \\
\hline 4 & Impotency/Infertility & 24 & 15 & 0 & 39 & 4 & 0 & 0 & 4 & 115 & 182 & 0 & 297 \\
\hline 5 & Family Problems & 5614 & 1873 & 0 & 7487 & 2058 & 661 & 0 & 2719 & 26975 & 13959 & 1 & 40935 \\
\hline 6 & Illness (Total) & 4483 & 1552 & 0 & 6035 & 2941 & 1321 & 0 & 4262 & 16274 & 7487 & 3 & 23764 \\
\hline & 6.1 AIDS/STD & 39 & 7 & 0 & 46 & 9 & 0 & 0 & 9 & 146 & 26 & 0 & 172 \\
\hline & 6.2 Cancer & 339 & 108 & 0 & 447 & 199 & 88 & 0 & 287 & 928 & 339 & 0 & 1267 \\
\hline & 6.3 Paralysis & 332 & 69 & 0 & 401 & 183 & 75 & 0 & 258 & 868 & 253 & 0 & 1121 \\
\hline & $\begin{array}{l}6.4 \text { Insanity/ Mental } \\
\text { Illness }\end{array}$ & 1654 & 609 & 0 & 2263 & 967 & 431 & 0 & 1398 & 7101 & 3032 & 1 & 10134 \\
\hline & $\begin{array}{l}\text { 6.5 Other Prolonged } \\
\text { IIIness }\end{array}$ & 2119 & 759 & 0 & 2878 & 1583 & 727 & 0 & 2310 & 7231 & 3837 & 2 & 11070 \\
\hline 7 & Death of Dear Person & 155 & 69 & 0 & 224 & 119 & 51 & 0 & 170 & 714 & 359 & 0 & 1073 \\
\hline 8 & Drug Abuse/Alcoholic Addiction & 1863 & 45 & 0 & 1908 & 588 & 7 & 0 & 595 & 7039 & 153 & 1 & 7193 \\
\hline 9 & Fall in Social Reputation & 114 & 18 & 0 & 132 & 23 & 3 & 0 & 26 & 399 & 123 & 2 & 524 \\
\hline 10 & $\begin{array}{l}\text { Ideological Causes/ } \\
\text { Hero Worshipping }\end{array}$ & 12 & 0 & 0 & 12 & 2 & 0 & 0 & 2 & 58 & 36 & 0 & 94 \\
\hline 11 & Love Affairs & 27 & 20 & 0 & 47 & 2 & 5 & 0 & 7 & 3077 & 2265 & 0 & 5342 \\
\hline 12 & Poverty & 236 & 26 & 0 & 262 & 70 & 9 & 0 & 79 & 1023 & 179 & 0 & 1202 \\
\hline 13 & Unemployment & 237 & 21 & 0 & 258 & 55 & 5 & 0 & 60 & 2431 & 310 & 0 & 2741 \\
\hline 14 & Property Dispute & 342 & 66 & 0 & 408 & 77 & 15 & 0 & 92 & 988 & 221 & 0 & 1209 \\
\hline 15 & $\begin{array}{l}\text { Suspected/ Illicit Relation } \\
\text { (Other than SI. No. 2.3) }\end{array}$ & 49 & 16 & 0 & 65 & 4 & 0 & 0 & 4 & 410 & 243 & 0 & 653 \\
\hline 16 & $\begin{array}{l}\text { Illegitimate Pregnancy } \\
\text { (Other than SI. No. 2.3) }\end{array}$ & 0 & 2 & 0 & 2 & 0 & 0 & 0 & 0 & 0 & 44 & 0 & 44 \\
\hline 17 & Physical Abuse (Rape, etc.) & 40 & 14 & 0 & 54 & 5 & 7 & 0 & 12 & 101 & 90 & 1 & 192 \\
\hline 18 & $\begin{array}{l}\text { Professional/Career } \\
\text { Problem }\end{array}$ & 293 & 43 & 0 & 336 & 83 & 12 & 0 & 95 & 1409 & 288 & 0 & 1697 \\
\hline 19 & Causes Not Known & 2008 & 487 & 0 & 2495 & 599 & 214 & 0 & 813 & 10054 & 4773 & 1 & 14828 \\
\hline 20 & Other Causes & 2252 & 695 & 0 & 2947 & 877 & 293 & 0 & 1170 & 11396 & 5451 & 2 & 16849 \\
\hline 21 & Total & 19708 & 5274 & 0 & 24982 & 8049 & 2647 & 0 & 10696 & 92114 & 42391 & 11 & 134516 \\
\hline
\end{tabular}

Note: 'M'- refers to Male, 'F'- refers to Female, 'Tr'- refers to Transgender and 'T' - Total

- As per data provided by States/UTs. 
Out of total 92,114 male suicides, maximum suicides were committed by daily wage earners $(26,589)$ followed by selfemployed persons $(12,175)$ and Unemployed Persons $(10,687)$. A total of 42,391 females committed suicides during 2018 in the country. 22,937 females who committed suicides were house-wives followed by students $(4,790)$ and daily wage earners $(3,535)$. A total of 11 transgender have committed suicide. Out of 11 transgender, 3 were daily wage earners, 1 each were 'Professionals/Salaried Persons' and 'Unemployed Persons' while 6 falls under 'Other Persons'.

State/UT-wise and profession wise analysis of suicide victims is presented in Table-2.7. Majority of suicides committed by house-wives were reported in Madhya Pradesh (2,876 out of 22,937 suicides) followed by Maharashtra (2,743 suicides) and Tamil Nadu (2,472 suicides) which accounted for $12.5 \%, 12.0 \%$ and $10.8 \%$ of total such suicides during 2018 respectively. Majority of suicides committed by government servants were reported in Maharashtra (231 out of 1,707 suicides) followed by Tamil Nadu (173 suicides), Madhya Pradesh (155 suicides), Karnataka (137 suicides) and Haryana (124 suicides) which accounted for $13.5 \%, 10.1 \%$, $9.1 \%, 8.0 \%$ and $7.3 \%$ of total such suicides respectively. Majority of suicides committed by persons engaged in Private Sector Enterprises were reported in Maharashtra (1,749 out of 8,246 suicides), Tamil Nadu (1,146 suicides), West Bengal (778 suicides), Karnataka (760 suicides) and Gujarat (685 suicides), they accounted for $21.2 \%, 13.9 \%$, $9.4 \%, 9.2 \%$ and $8.3 \%$ of total such suicides respectively. $14.3 \%$ of total suicides committed by students were reported in Maharashtra (1,448 suicides) followed by $9.4 \%$ in Tamil Nadu (953 suicides), $8.5 \%$ in Madhya Pradesh (862 suicides), $7.4 \%$ in Karnataka (755 suicides) and $6.0 \%$ in West Bengal (609 suicides). Majority of suicides committed by un-employed persons, $12.3 \%$ were in Kerala (1,585 out of 12,936 suicides), $12.2 \%$ in Tamil Nadu (1,579 suicides), $9.7 \%$ in Maharashtra $(1,260$ suicides), $8.5 \%$ in Karnataka (1,094 suicides) and $7.0 \%$ in Uttar Pradesh (902 suicides). Majority of suicides committed by persons engaged in business activities were reported by Karnataka (13.9\%), Maharashtra (12.1\%), Tamil Nadu (11.7\%), West Bengal (8.9\%) and Kerala (8.1\%). Majority of victims engaged in farming sector were reported in Maharashtra (34.7\%), Karnataka (23.2\%), Telangana (8.8\%), Andhra Pradesh (6.4\%) and Madhya Pradesh $(6.3 \%)$.

\section{Social Status of Suicide Victims}

Social Status of victims is classified in seven categories namely 'Un-married', 'Married', 'Widowed/Widower', 'Divorcee', 'Separated', 'Others' and 'Status Not Known'.

The information on the social status of suicide victims is presented in Table- 2.8(I). It is observed that $68.8 \% \quad(92,533$ out of $1,34,516)$ of the suicide victims were married while $22.7 \%$ were un-married $(30,503)$. Widowed/Widower, Divorcees and Separated have accounted for $1.7 \%$ (2,329 victims), $0.7 \%$ (943 victims) and $0.6 \%$ (849 victims) of total suicide victims respectively during 2018.

The State/UT-wise information on the social status of suicide victims is presented in Table-2.9.

\section{Economic Status of Suicide Victims}

The information on the economic status of suicide victims is presented in Table- 2.8(II). $66.2 \%$ of suicide victims in 2018 were having annual income of less than ₹1 lakh $(88,986$ out of $1,34,516$ victims). $29.1 \%$ (39080 out of $1,34,516$ victims) of suicide victims belong to annual income group of '₹1 lakh \& above to less than ₹5 lakh'. The State/UT wise information on the Economic Status of suicide victims is presented in Table-2.10.

\section{Educational Status of Suicide Victims}

The sex-wise and education-wise breakup of suicide victims is presented in Table2.8(III). The maximum numbers of suicide victims $(23.6 \%) \quad(31,757$ out of $1,34,516$ victims) were educated up to Matriculation/ Secondary level. Middle level educated, Primary educated, Hr. Secondary/ Intermediate/Pre-University educated and Illiterate persons accounted for $19.5 \%(26,252$ out of $1,34,516$ victims), $17.1 \%$ (23,048 out of $1,34,516$ victims $), \quad 16.4 \% \quad(22,076$ out of $1,34,516$ victims) and $12.7 \%(17,026$ out of $1,34,516$ victims) respectively of total suicide victims during 2018 . Only $3.3 \%(4,437$ out of $1,34,516$ victims) of total suicide victims were graduates and above during 2018. 
Figure - 2.7

Distribution of Suicide Victims by Social Status during 2018

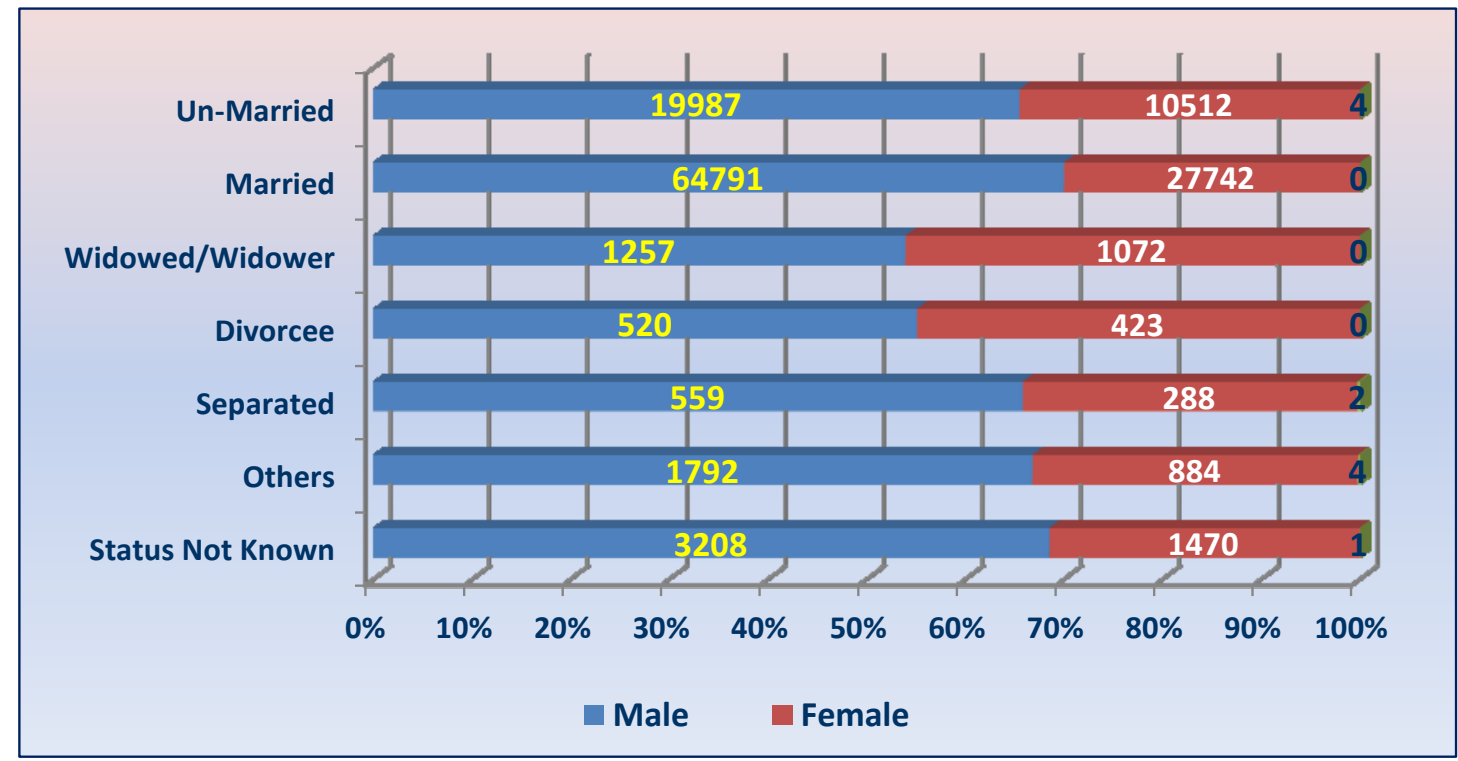

- $\quad$ As per data provided by States/UTs.

Figure - 2.8

Percentage Share of Suicide Victims by Educational Status during 2018

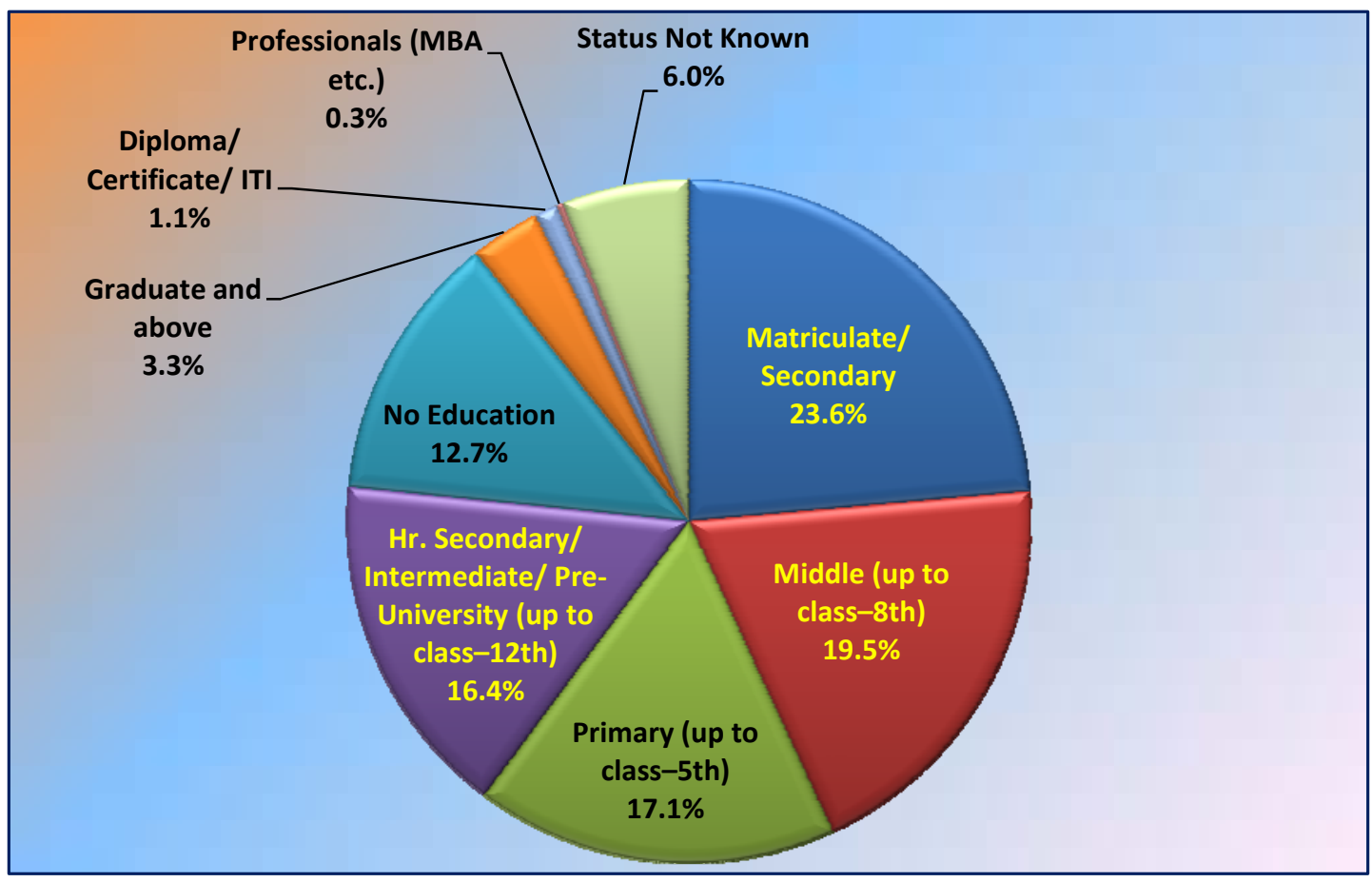

- As per data provided by States/UTs. 
Table - 2 (F)

Percentage of Suicide Victims by Educational Level during 2016 - 2018

\begin{tabular}{clccc}
\hline \multirow{2}{*}{ SI. No. } & \multicolumn{1}{c}{ Educational Level } & \multicolumn{3}{c}{ Percentage Share } \\
\cline { 3 - 5 } & \multicolumn{1}{c}{$(\mathbf{2})$} & $\mathbf{2 0 1 6}$ & $\mathbf{2 0 1 7}$ & $\mathbf{2 0 1 8}$ \\
\hline $\mathbf{1})$ & No Education & 13.8 & $\mathbf{( 4 )}$ & $\mathbf{( 5 )}$ \\
\hline 1 & Primary Level & 18.3 & 13.0 & 12.7 \\
2 & 20.1 & 16.3 & 17.1 \\
3 & Middle Level & 19.4 & 19.5 \\
4 & Matriculate/Secondary Level & 22.6 & 23.6 & 23.6 \\
5 & Higher Secondary Level & 12.8 & 15.9 & 16.4 \\
6 & Diploma & 1.1 & 1.2 & 1.1 \\
7 & Graduate \& above & 3.1 & 3.5 & 3.3 \\
8 & Professionals (MBA etc.) & 0.2 & 0.3 & 0.3 \\
9 & Status Not Known & 8.1 & 6.8 & 6.0 \\
\hline $\mathbf{1 0}$ & Total & $\mathbf{1 0 0 . 0}$ & $\mathbf{1 0 0 . 0}$ & $\mathbf{1 0 0 . 0}$ \\
\hline
\end{tabular}

- As per data provided by States/UTs.

The State/UT wise information on the Education Status of suicide victims is presented in Table- 2.11.

Out of 31,757 suicides committed by persons educated up-to matriculate/secondary level, $17.2 \%$ were reported in Maharashtra followed by Kerala (10.4\%) and Tamil Nadu (10.1\%). Out of 26,252 suicides committed by persons educated up-to middle level, $14.5 \%$ were reported in Maharashtra followed by Tamil Nadu (11.6\%) and Madhya Pradesh (10.0\%). Out of 17,026 suicides committed by persons with no education $15.5 \%$ were reported in Telangana followed by Madhya Pradesh (12.3\%) and Tamil Nadu (11.1\%) [Table-2.11].

Percentage share of suicide victims by educational level during $2016-18$ is presented in Table-2(F).

\section{Means Adopted for Committing Suicides}

The means adopted for committing suicide varied from the easily available and effective means such as consumption of poison, jumping etc. to more painful means such as self-inflicted injuries, hanging etc. Like previous year, 'Hanging' (51.5\%), consuming 'Poison' (26.7\%), 'Drowning' (4.9\%) and 'Fire/SelfImmolation' (4.4\%) were the prominent means/mode of committing suicide. [Table 2.12]

Percentage share of the means adopted in committing suicide during $2017-18$ is presented in Table-2(G).
During the year 2018, the share of 'Fire/Self Immolation (from $5.3 \%$ in 2017 to $4.4 \%$ in 2018 ) and 'By Poison' (from $27.5 \%$ in 2017 to $26.7 \%$ in 2018) as mode adopted by suicide victims has decreased while share of 'Hanging' (from 49.8\% in 2017 to $51.5 \%$ in 2018), 'By Drowning (from $4.8 \%$ in 2017 to $4.9 \%$ in 2018), and 'By Jumping' (from $1.7 \%$ in 2017 to $1.9 \%$ in 2018 ) have increased during 2018 over 2017. [Table - 2(G)]

The sex-wise break-up and means adopted for suicide in various States/UTs is presented in Table-2.13.

Table - 2 (G)

Percentage of Means/Mode Adopted by Victims to Commit Suicide during 2017-2018

\begin{tabular}{|c|c|c|c|}
\hline \multirow[t]{2}{*}{ SL. } & \multirow{2}{*}{ Means/Mode Adopted } & \multicolumn{2}{|c|}{ Percentage \& Number } \\
\hline & & 2017 & 2017 \\
\hline (1) & (2) & (3) & (4) \\
\hline 1 & Consuming Sleeping Pills & $0.8 \%(1,015)$ & $0.7 \%(939)$ \\
\hline 2 & Drowning & $4.8 \%(6,235)$ & $4.9 \%(6,579)$ \\
\hline 3 & Fire/Self Immolation & $5.3 \%(6,858)$ & $4.4 \%(5,950)$ \\
\hline 4 & Firearms & $0.4 \%(480)$ & $0.4 \%(521)$ \\
\hline 5 & By Hanging & $49.8 \%(64,705)$ & $51.5 \%(69,306)$ \\
\hline 6 & By Poison & $27.5 \%(35,671)$ & $26.7 \%(35,862)$ \\
\hline 7 & By Self inflicting Injury & $0.8 \%(975)$ & $0.6 \%(772)$ \\
\hline 8 & By Jumping & $1.7 \%(2,203)$ & $1.9 \%(2,557)$ \\
\hline 9 & $\begin{array}{l}\text { By Coming under Running } \\
\text { Vehicles/Trains }\end{array}$ & $2.9 \%(3,816)$ & $2.9 \%(3,848)$ \\
\hline 10 & By Touching Electric Wire & $0.4 \%(560)$ & $0.4 \%(565)$ \\
\hline 11 & By Other Means & $5.7 \%(7,369)$ & $5.7 \%(7,617)$ \\
\hline 12 & Total & 100.0 & 100.0 \\
\hline
\end{tabular}

- As per data provided by States/UTs.

The number of male victims were more than females in all means of suicide except those who committed suicides by 'Fire/Selfimmolation' where share of female victims was more $(3,809$ out of 5,950$)$. 


\section{Suicides in Cities}

City refers to mega city i.e. city having population of $10,00,000$ or more.

The numbers of suicides in 53 mega cities show an increasing trend during 2015 to 2018. It increased by $6.2 \%$ (from 19,665 in 2015 to 20,879 in 2016) and increased by $1.8 \%$ (from 20,879 in 2016 to 21,240 in 2017). It increased by $0.8 \%$ (from 21,240 in 2017 to 21,408 in 2018). Details on year-wise incidents in cities, percentage share to All-India, rate of suicides and percentage change during 2015 - 2018 may be seen in Table-2(H).
'Marriage Related Issues' accounting for 4.8\% of total suicides in the cities.

\section{Mass/Family Suicides}

This section provides information on the number of cases where family members have committed suicide jointly. Out of 36 States/UTs, Mass/Family Suicides were reported in 11 States during the year 2018. State/UT \& Citywise information on mass/family suicides is presented in Table-2.14.

Table - 2 (H)

Incidence of Suicides in Mega-Cities, percentage share to All-India, rate of suicides and percentage change over previous year during 2015 - 2018

\begin{tabular}{ccccc}
\hline Year & $\begin{array}{c}\text { Suicides in } \\
\text { Cities }\end{array}$ & $\begin{array}{c}\text { Cities Share to } \\
\text { All India }\end{array}$ & $\begin{array}{c}\text { Rate } \\
\text { in Cities }\end{array}$ & $\begin{array}{c}\text { \% Variation over Previous } \\
\text { Year (Incidence) }\end{array}$ \\
\hline 2015 & 19,665 & 14.7 & 12.2 & 0.3 \\
2016 & 20,879 & 15.9 & 13.0 & 6.2 \\
2017 & 21,240 & 16.4 & 13.2 & 1.8 \\
2018 & 21,408 & 15.9 & 13.3 & 0.8 \\
\hline
\end{tabular}

- As per data provided by States/UTs.

The four Metropolitan Cities - Chennai $(2,102)$, Delhi City $(2,369)$, Bengaluru $(2,082)$ and Mumbai $(1,174)$ have reported higher number of suicides. These four cities together have reported almost $36.1 \%$ of the total suicides reported from 53 mega cities. Kolkata and Chennai Cities have shown a declining trend during 2018 over 2017. Delhi City has shown an increase of $8.2 \%$ (from 2,189 suicides in 2017 to 2,369 suicides in 2018) and Bengaluru has observed an increase of $2.5 \%$ (from 2,032 suicides in 2017 to 2,082 suicides in 2018). [Table - 2.3].

The suicide rate in cities (13.3) was higher as compared to All-India suicide rate (10.2). Kollam followed by Durg-Bhilainagar have reported the highest suicides rate of 35.4 and 33.1 respectively. [Table-2.2].

'Family Problems (other than marriage related issues)' was the major cause of suicide in cities which accounted for $37.7 \%$ (8,069 out of 21,408 ) of total suicides followed by 'Illness' $(17.7 \%)(3,788$ victims out of 21,408 victims). However, a total of 1,027 victims have committed suicide in 53 mega cities due to
A total of 64 cases of mass/family suicides were registered during the year 2018. In these 64 cases of mass/family suicides, a total of 173 persons, comprising of 119 married persons and 54 unmarried persons, have committed suicides during 2018.

Maximum cases of mass/family suicides were reported Tamil Nadu (15 cases) followed by Andhra Pradesh (11 cases), Madhya Pradesh (9), Punjab \& Rajasthan (6 cases each) and Kerala (5 cases) during 2017. A total 35 persons in Tamil Nadu, 26 persons in Andhra Pradesh, 24 persons in Kerala and 22 persons in Uttarakhand have committed mass/family suicides during 2018 [Table-2.14].

Out of 53 cities, mass/family suicides were reported in 6 cities. These six cities have registered 9 cases of mass/family suicides in which 22 persons have committed suicides during 2018. Among these 22 persons, 17 were married and 5 were unmarried persons [Table-2.14]. 